\title{
Peculiarities of the Structure and Distinctive Features of the Interpretation in "Motley Tales with Witticisms" by V. F. Odoyevsky
}

\author{
T.P. Vorova \\ Docent, Candidate of Philological Sciences, \\ Department of foreign languages for humanitarian specialities, \\ Oles Honchar Dnepropetrovsk National University, \\ E-mail address: kryptos11@mail.ru
}

Keywords: fairy tale, narrator, writer's alter ego, image-symbol, symbolism of numbers, alchemy, hermetism.

\begin{abstract}
Prince V.F. Odoyevsky (1803-1869) was the Russian writer, philosopher, musicologist and subtle musical critic, public figure, founder of «Society of philosophy-lovers» and author of «Motley Tales with Witticisms», fascinating monument of native culture; the book was published only once during the life of the writer and afterwards was not republished as the cycle. In literary criticism «Motley Tales» as the unified and important cycle by V. F. Odoyevsky were given scant coverage, although this literary work marked the beginning of new period in the writer's oeuvre; an image of narrator Homoseyko is especially interesting because it is not only the intellectual hero, but also the alter ego of the writer. «Motley Tales» manifest a unique opportunity of watching the rising of themes and motives which will be revealed in the writer's creation later, as well as following the formation of philosophical, aesthetic and artistic principles of author, as his fairy tales include the patterns of philosophical grotesque, social and moralizing story, folklore / psychological fantasy.
\end{abstract}

\section{Introduction.}

V. F. Odoyevsky's cycle of works «Motley Tales with Witticisms, collected by Irineus Modestovich Homoseyko, master, philosopher and member of different scientific societies, edited by V. Bezglasny» was first published at the beginning of 1833 . The publication of this book was greeted with controversial reviews from the critics and lively interest from readers. Modern specialists in the study of literature (M.Turian [12, 13, 14], V. Sakharov [10], V. Zhirmunsky [2[ et al.) concentrate their attention on several works from the whole cycle (Tale of a Dead Body, Tales of Girls, Igosha), which are considered to represent socially-oriented criticism because of their content, but the other fairy tales are disregarded as unworthy of consideration from point of view of social criticism. However, all works from the analyzed collection are integral parts of the cycle (M. Turian rightly emphasizes the characteristic cyclical thinking of the author [15, p. 3]), which is why all these fairy tales deserve to be considered as important components of a uniifed fabulous cycle.

\section{Discussion.}

Initially, there was a different author's variant of the title of the collected fairy tales - «Terry Fairy Tales», interpreted a unsmoothed / tattered. However, the word terry (rough textured) is changed for motley, in which there is a subtle shade of meaning quarrelsome / cunning in addition to colourful. In view of the aforesaid, the focus is transmitted from the initial meaning of trivialities of little value to the diversity of the material, presented in a humorous, unserious tone, but simultaneously with a shade of laughter, in a sophisticated intricate style, archly concealing the secret context, for which the readers (unaided) will have to choose the conceptual keys, unable to rely on any help from the author with his apparent simplicity of style.

The cycle «Motley Tales» consists of 1) Editor's Preface; 2) Author's Preface; 3) The Retort (the only tale from the cycle divided into 4 chapters); 4) Tale of a Dead Body Belonging to No One Knows Whom; 5) The Life and Adventures of One of Our Local Inhabitants in a Glass Jar; 6) Tale of How it Happened that a Collegiate Councillor Ivan Bogdanovich Otnoshenye Failed to Offer 
Holiday Greetings to his Superior on Easter Sunday; 7) Igosha; 8) Just a Tale ; 9) Tale of How Dangerous it is for Girls to Walk in a Crowd along Nevsky Prospect; 10) The Same Tale, Only in Reverse: 11) The Wooden Guest, or the Tale of the Awakened Doll and Mister Kivakel; 12) Epilogue [7]. Thus, a twelve part structure is presented, in which three parts form the framework (the symbolism of number three means multiplicity, creative power, growth; the triad embodies a single whole, as it contains the beginning, middle part and the end), nine fairy tales represent the basic content (the symbolism of number nine is the power of the triple triad, it is a celestial and angelic number); the sum of the two numbers is twelve (this symbolizes spiritual and temporal order, esoteric and exoteric things). The numerological symbolism of the contents reveals the author's hidden intention: to show the trinity of the world and the cyclical trinity of man in the unity of the divine Creator of the universe. That is why it is important to trace the implementation of the numerological symbolism in the ideological space of this fabulous cycle by V. F. Odoyevsky, who attempted to lend the attractive shape of alchemical language to his ideas as well, because only in the symbolism of alchemy could the author see the possibility to give the most effective embodiment to the secret knowledge connected with the principles of triad, ennead and dodecad.

Before beginning the analysis of the fabulous text, it is worth discussing the double image of the publisher / story-teller V. Bezglasny/I. M. Homoseyko, representing the author. The idea that the narrator Irineus Modestovich Homoseyko embodied the alter ego of V. F. Odoyevsky was exposed for the first time by P. Sakulin in 1913 [9]. The same conception is convincingly supported by the contemporary researcher of the writer's creative activity - M. Turian [15]. The indistinct image of the editor and the more clearly delineated image of the writer are combined with the emotional, psychological and intellectual aspects of the personality of V. F. Odoyevsky, who provided for the reader's attention some information on his own way of life in the form of mystical philosophical fairy tales. Two faces of the author's personality become apparent behind the image of editor / writer: the first one is that of a cold, rational and socially-oriented editor (he is V. Bezglasny because his opinion is not important in the work, i. e. this aspect of the writer's personality is not essential), he keeps himself aloof from the narration, giving free rein of expression to the second face of the author, who is, actually, a writer of fairy tales. The aspects of personality and ideological principles of the second image are extremely interesting and differ greatly from the glossy salon sleekness of the first image. He is shy and modest, but at the same time he is honest and frank, not afraid to open up some of his secret preferences, methodical and widely-read, although sometimes he can look a bit ridiculous and naive. He reveals his soul in the artless desire to attract the attention of the same enthusiastic people as he is. In common with the duality of editor / writer, his tales are also two-dimensional, with a double foundation. They start with the name of the writer: from the Greek language the root of his name is translated as temple, sanctuary, and the Latin word homo (the basis of Homo-seyko) means just a man. The patronymic Modestovich is interpreted in Latin as moderate, reasonable, prudent and modest. Thus, taken together, the first name, patronymic and surname represent a modest temple of a man who sows the good seeds in the soul. At the same time, the word Irineus from the Old Russian language means paradise, so the interpretation of the name might be a modest paradise for people. As a result, the name stands for a modest / abundant paradise / temple of the human soul.

In the description of the the level of education of the writer, a great deal of esoteric information is introduced: the direct introduction of the Latin titles of certain esoteric books and the names of scientist-alchemists, well-known because of their research in this mysterious science. The writer (Master of Philosophy and a member of various scientific societies) as an alter ego of V. F. Odoyevsky affirms one of his «wretched weaknesses»: «I'm just a scientist» [7, p. X]. And a little further on, he develops the same idea of himself: as a thinking person, «thoroughly dejected with my knowledge, I sometimes want to manifest this to society» [7, p. XII-XIII]. In order to maintain a pseudo-scientific form of the narration, the chapter «From the editor» is created with deliberate logicality; in no uncertain terms, the author introduces the phrase «logical hierarchy» that focusses the reader on the absence of chaos and randomness, pointing to the logical regularity of the events 
described in the nine following fairy tales. It is necessary to recall again the numerological importance of numbers when one deals with the alchemical Magnum Opus or The Great Work: it means the functioning of the principle of the Trinity in the four worlds $(3 \times 4=12)$, where the trinity can represent different notions ( 3 aspects of the Triune God; 3 symbolic substances sulphur, mercury, salt and 3 components of a human being - body, soul, spirit, and so on), the number 4 includes the four levels of the universe (the God, man, the elemental level and the chemical elements), whereas 12 is the basis of the Great Work and its finish which completes the alchemical process of growth and augmentation resulting in the alchemist's discovery of the Philosopher's Stone, so patiently sought and desired (without which the alchemical mystery of the three worlds becomes impossible). Therefore, the symbols and secret signs of the Great Work hide three aspects of the mystery of conversions and transformations taking place in the inner world of man, because the first, most powerful alchemy occurs in the human soul, and only then can a person carry out the lesser alchemy in the retort (turning the base metals into gold). However, one should start with the simple chemical retort.

«The Retort» is the title of the first fairy tale in the collection, but it takes the third place according to its order (after the two introductions of the editor and writer), and has four of its own chapters. Consequently, the sacred decade of alchemists is hidden here. The symbolism of the number 10 is matched with the contents of the chapters of this fairy tale: 1) Introduction; 2) How the Writer Knows Why It Is so Stuffy in the Parlour; 3) What Happens with the Writer When He Is in the Retort; 4) How the Writer Appears in the Latin Dictionary and What He Sees There. The contents of the first chapter corresponds to its title - it is really the introduction to a very important area (from the point of view of the author) of the ancient esoteric alchemical knowledge. The author candidly admits that he is engaged in studying these sciences, but he is not very successful in their practical use. But he is aware of the significant role of philosophical calcination, sublimation and distillation (alchemical terms). Moreover, the author has personal experience in the field of alchemy, and he prepares to relate this with a proper seriousness. In accordance with the chosen alchemical direction, the next three chapters in this fairy tale illustrate step-by-step three important alchemical processes - distillation (the 2nd chapter), calcination (the third chapter), or sublimation (the 4th chapter). The author specifically introduces these three terms into the text with the attribute «philosophical» [7, p.12], therefore they should be understood in direct and figurative meanings.

The second chapter describes a ball (where the writer is also present), and it becomes clear that the whole house with the presented guests is mysteriously transferred into a retort, and some «damned Chemist has unmercifully distilled the respectable audience! ...» [7, p.17]. The people in the parlour are under the supervision of someone else who is at a completely different level, and in a figurative sense a stratification is presented of the mini-society from the ball into factions or groups according to their interests. But only the observant writer-narrator is able to perceive the artificial creation of heat / pressure in the mini-society and decides to find out more about the experimenter on people. The third chapter depicts the direct and figurative meanings of calcification - the process aiming at the decomposition of a substance. In a figurative meaning it is a separation: the hero leaves the society and meets the experimenter - an impudent 5-year-old demon or imp (it gives the author an opportunity to draw the sad conclusion that this is possible due to the dominance of positivism and customary prudence in the society). The hero dares take a responsible step - to oppose himself to the «universal evil» (in the image of imp), since someone who sees and supports positivism serves the forces of «darkness and oppressiveness» (in direct and figurative meanings) or, simply, the forces of evil.

Finally, in the last chapter a description is introduced of the process of sublimation: at a material level it represents the transition from one chemical state to another, but in a figurative meaning it is the transference of energy of inferior impulses to higher purposes. In accordance with the above-mentioned concepts, the hero considers the necessity of ascending to the delightful and lofty states of love, kindness, intelligence, being aware of the fact that there is no easy path to them, and that all mistakes should be attributed only to people. The hero obtains the unusual ability to become permeable (it is illustrated with the incident of overflowing through the pages of the 
Latin dictionary, where he is put by the little imp) and to transfer certain aspects of his personality to the beings he meets (a spider, a dead body, Igosha, etc.), which are image-symbols reflecting some sides of the hero's ego. This is the beginning of the real sublimation (i. e. the crystallization of certain qualities and characteristics of the hero) described in a comparison of the new strange acquaintances and the hero himself.

The contact and communication of the hero with his new acquaintances is so powerful and effective that the process of transformation and transmutation starts in the hero himself (he is starting to turn into a «fairy tale» [7, p. 25]) and in this literal form is introduced a human being as an informative matrix with possible deviations from a certain standard, but with the loss of human nature and the subsequent transformation into an object (book). The author introduces another image-symbol, where human life is represented as an equivalent of a book where the information about all possible events in human personal life is printed in advance. However, even without the evil actions of the imp the hero has to make considerable efforts to revive the human features inside himself; but his new friends remain in the same form, although the narrator (only because of curiosity) decides to represent them to the readers' consideration.

The plot of the next fairy tale («Tale of a Dead Body Belonging to No One Knows Whom») seems like a joke: a dead human body is found exhibiting no signs of a violent death; a policeman Sevastianych has to write a conclusion which will permit the burial of the body. While writing the report, Sevastyanych drinks a shtoff (1.2 litres) of home brewed liqueur (quarter by quarter at regular intervals) and eats up a goose. Then, the soul of the ownerless body appears and insistently asks the policeman to return his body for 50 rubles, because it is extremely uncomfortable to be without a body. Sevastianych writes a formal request aiming at returning the body and goes to bed; in the morning he and his request are ridiculed and the body is buried. From the writer's lifetime up to the present this story has been considered as an artistic work with socio-satirical orientation. Yet, this view is not quite adequate because it does not take the whole contents of the cycle into consideration. More careful and attentive reading reveals the following numerological symbols (the body is found on November, 21; the report is written in 21 days - on December, 12; the body is buried December, 13; but every morning over 20 years the soul visits Sevastianych with the same request to return its body), etc. The seemingly comic narrative frame forms the background for a hidden esoteric meaning. All the dates correspond with the meaning of the Major Arcana of Tarot $(3,7,12,13,20.21)$, whose energy can have a huge impact on the different stages of alchemical activity; in the context of the fairy tale they introduce the following summarizing information: the incarnated soul (Arcanum 3) through different situations (Arcanum 7) is taught to live in the material world (Arcanum 21), but the soul is always in an unstable suspended state (Arcanum 12), because the body is given for temporary (not permanent) use; death (Arcanum 13) comes at the end of life, and then the soul must render an account (Arcanum 20) of the work it has performed. The principal attention is focused on the annual cycles of human life: this is underlined with the image-symbols of the goose and the methodically listed first, second, third and fourth quarters of liqueur, drunk by Sevastianych. As a solar symbol, the goose indicates the decreasing or increasing power of the sun (the main action of the fairy tale, i. e. writing the report about the dead body, takes place on December, 12 - the day of the winter solstice (according to the Russian Orthodox calendar), and the body is buried on December13, which is connected with the weakest level of solar activity and the symbolism of Arcanum 13 «Death»).

The four quarters are directly associated with the four periods of the annual cycle (spring, summer, autumn, winter) and human life (childhood, adolescence, adulthood, old age). Therefore, the conversation of Sevastianyh with the soul is possible only when the shtoff bottle is empty (the symbolism is simple and evident: the body has spent all its vital energy and on the threshold of death it is in direct contact with its own soul). In addition, once again the symbolism is used of the number 12 (due to its importance, it is duplicated with number 21, that is the same dozen, but in reverse), an important number of Jupiter; it indicates the presence of spiritual symbolism (that is also closely connected with alchemy) and mystery / initiation. So, the allegory used, along with related associations, is beyond doubt. The fairy tale ends with a mention of 20 years, the 
numerological symbol of Jupiter and Saturn, which is the key to the interpretation of the following tale - «The Life and Adventures of One of Our Local Inhabitants in a Glass Jar, or the New Zhoko» with the subtitle «A Classical Tale». The content is based on the classical scheme of many life stories (which is why it is subtitled "A Classical Tale»," i. e. everything is the same as with other people). The protagonist is a young spider from an ancient noble family Arachnid / Aranend. He has a cruel father, who destroys all around him, including his own children. The hero runs away from home and in this way escapes from being eaten by his cruel father. He meets his beloved and starts a family - everything is the same as with human beings. But the formidable father pursues his son even to his new home, fiercely destroying his family. The hero accidentally falls into a trapjar, which is broken by accident. M. Turian conducted some interesting research on the origin of the name Zhoko [15, p. 13-17] and found that it was the name of a monkey from a popular French sentimental novel 'a la Rousseau by S. Puzhanu: the monkey brought up a boy and later became his victim. M. Turian states that V. F. Odoyevsky copied out the apocalyptic passions of the French novel written at the beginning of the XIX-th century in the form of parody. However, the plot of the fairy tale is striking in its similarity with the myth about cruel Kronos devouring his children. It is well-known that this mythical image is the embodiment of the inexorable destructive activity of time, influencing all living things in the material world. But Kronos is identical to Saturn, the god of time, symbolizing infinity and the boundlessness of time; the Greeks called this dark and cold planet Father-Time. This idea is closely connected with the main narrative frame of the fairy tale, representing a key to the interpretation of events, except for one important final scene, when the escaping hero finds himself in a kind of prison - a glass jar which delights the hero with its beauty. This jar-prison is the image-symbol of the beautiful material human body, which, according to alchemists, is a prison for the human soul.Therefore, inside the body-prison the hero is again pursued by cruel Father-Time and the meeting with him will inevitably have a lethal outcome. But an unexpected miracle happens - the glass walls are broken, and cruel Father-Time disappears at the moment of destruction of the physical body. The conclusion of this alchemical allegory is simple: in order to avoid the inexorable impact of time it is necessary to destroy the physical boundaries of the material form of existence, i. e. to destroy the physical body and to liberate the soul from its material captivity. In general, the fairy tale demonstrates the specifity of space and time as the forms of existence on the Earth, where time / Kronos devours his own creations.

The fairy tale IV is about the collegiate advisor Ivan Bogdanovich and his love for card games; after work he passionately devotes himself to excitement from card games with three companions at home. On the eve of Easter they play all night and morning, miss matins and the liturgy in the church and, in the end, the cards take over the gamblers: the cards come to life and take the place of the players, whereas the players turn into cards. Despite its small volume and evident social criticism, this fairy tale is the same as the previous ones, with its hidden context, double foundation, containing secret keys to understanding. Firstly, this fairy tale is chronologically linked with the second one (of the dead body), in which the action takes place on the day of the winter solstice, whereas the action from the fourth tale happens several months later, during the most significant holiday according to the church calendar, the day of the powerful spring renewal of nature and, analogically, of human beings, who have the possibility to purge themselves from their old sins, destroy the overburdening action of law of cause and effect which prevents human soul from undergoing spiritual evolution. Not without reason, this holiday is prepared for in the most careful way over the previous weeks, through the night before and the culminating ritual celebration on Sunday. Over the whole Lent period many aspects of everyday life are regulated - eating, drinking, taking care of the home, clothing, the body, behaviour, treatment of other people, etc. Therefore, the criminal actions of the gamblers were obvious to the XIX-th century reader, brought up in the Orthodox culture. Naturally, the focus should be transferred from social criticism to the fundamental qualities of human spirituality. There is no doubt that the fairy tale depicts a more subtle informative layer, connected with the description of a sin of the soul - the card game. But are the cards of the heroes so simple? It should be remembered that in a latent form the cards have already appeared in the second fairy tale. The Major Arcana consists of 22 cards, while the 
remaining 56 cards comprise the Minor Arcana, presented in a simplified form in the familiar pack of cards; their initial variant and the appropriate interpretation is beyond the level of understanding of uninitiated people who have no esoteric perception of the mysterious pack of Tarot. The key scene in the fairy tale is introduced in the final episodes [7, p. 85-87], when the players suddenly realize that they have no control over their bodies, actions, thoughts, as they are governed by the supernatural power of cards. Without even being aware of it, the silly players (playing during Easter) give to the cards tremendous strength and power, bringing into operation a collective computer, mechanism of action, with the principle of control and functionality that are completely unknown to them, and they probably have never known about the existence of such kind of mechanism. The players are fully subjugated by the suddenly transformed Arcana (they speak, act, command, bend in their will real people). There is an amazing detail: only Queens are playing at the table. In this form the writer demonstrates the popular alchemical statement about stagnation, inertness, inactivity of the physical substance (Queens embody just this substance in four forms). This fact will be mentioned again in the analysis of «Just a Tale».

In the fifth fairy tale «Igosha» the father of the little hero meets some cabmen in a tavern who put aside some food for somebody else. When asked about the purpose of their actions, they reply that the food is destined for Igosha - an evil spirit who likes to play tricks on people. As a joke, the incredulous father of the little hero offers to take Igosha to his home. On the way he faces different troubles, at home the little hero sees Igosha, who takes the boy under the personal patronage (in practice this means the beginning of a series of troubles in the life of the little hero). M. Turian is convinced that V. F. Odoyevsky plunges into his own childish consciousness and represents the psychologically intricate structure of interaction between the world of a child and an adult $[15$, p. 22]. This is undoubtedly an important observation. However, another explanation should be added. In the context of this cycle, the «armless, legless»" spirit is the personification of the «clear» soul which is incarnated on the Earth for the first time. It is no wonder that Igosha's appearance is formless and sexless, as a soul is a clot of energies without sexuality. A soul begins to live «from scratch», without taking into account the wide range of laws, rules and conventions in society, which, undoubtedly, must be followed in order to avoid possible troubles. The absurd logic and, as a consequence, illogical behaviour of Igosha gives rise to contradictions between the tiny soul and its boy-bearer, on the one hand, and between the boy and the surrounding world, on the other hand, because positive things from the world of a soul are believed to be negative in the world of human beings and vice versa. Igosha/a soul performs reasonable actions from his point of view, but they are estimated as senseless by adult people who see (in these actions) only the disturbance of the established lifestyle and irrationality. The writer gently indicates the fact that Igosha/a soul came to the Earth to live and study, cognize the world in games, his own games which are not understood by other people, who, in their turn, also have their own games, the importance of which is impossible for Igosha / a soul to grasp. As a result, there is a conflict and misunderstanding between the different worlds. It is no wonder that Igosha, who often hears the reproaches from the little boy, calls him «ungrateful». As a matter of fact, this is the first model of psychological fiction in the creative oeuvre of V. F. Odoyevsky.

The sixth «Just a Tale» is about different things in a room which come alive when their host falls asleep; then the things sort out their relationships. The contemporaries of the writer saw this work as a poor imitation of Hoffmann because of the combination of the domestic, fantastical and realistic aspects and motives in this fairy tale which easily turn into one another. However, there is another aspect of textual interpretation, connected with the two main leading objects in the room: a white knitted cap from the host's head and a red shoe with a button. Their appearance is directly linked with the idea of existence of monad: it is united, but divided into polarities of yin / yang at the same time. This interpretation is a result of the sexual characteristics of the cap and shoe's behaviour. The cap is a leader by his nature, looks down on other things, sitting in an armchair - a direct hint at the habit of the human mind to philosophize about everything; when a thought comes to him, the hero «grimaces», «the stitches [i.e. the brain cells] are in a convulsive movement» [7, $p$. 109]. The shoe appears «flirting and spinning on her heel» [7, p.107], she is «a wonder of nature», 
with features of «stunning beauty», but «frivolous» [7, p. 112]; she constantly argues with the cap. «The gentle babbling of the shoe» is always in the cap's ear, persuading him to perform the actions which are inconsistent with his pattern of behaviour; however, her good looks appeal to the hero, and the cap, «humming softly», agrees to follow her without listening to the good advice of others. One more important conceptual level, introduced into the narration, is the existence of religions and the specificity of the religious ideas which impose restrictions on the human mind. The cap and the shoe in this context are shown as representatives of different religious confessions and, consequently, different religious ideologies. The cap supports a religion whose doctrine includes the existence of knitting needles, stitches and the hosiery master; a prophet for him is a soap box that sets him on the right path in critical situations. Later, the cap will cry bitterly, remembering the apocalyptic forecast of the soap box: like the biblical prodigal son, he will rush back to his native religion from the inhospitable and uncomfortable religion of the shoe, which is completely different from the high ideas of the white cap. The shoe starts her Jesuit work of religious temptation with the introduction of doubt with regards to the correctness of cap's religion. For this purpose she asserts the doctrine of the supremacy of the cobbler over the hosiery master; consequently, everyone who does not recognize the domination of the «great cobbler» is a foolish creature with a clouded understanding. The shoe makes fun of the initial faith of the cap, presenting all advantages of her religion. The silly cap finds something high and mysterious in the words of the seductress and voluntarily rejects his own religion. Everything ends in predictable tragedy when the white cap is covered with black shoe polish. This allegory is easy and leads to understanding of the fairy tale as the description of the classical struggle between black and white, light and darkness, God and devil, heaven and earth for the white (i.e. immaculate by its nature) human soul. The soul is allured by material benefits as a form of sin, it is tempted by beautiful life on the Earth, but the weight of cares and suffering of hardships are hidden from it. There are four elements in the narration necessary for every mystery/initiation: the existence of poles of light/darkness, descent into darkness, and ascent into light. The symbolism of the sleeping host is also simple and trivial: it is God himself (i.e. He is the only character with a proper name, the other actors are described just by their common generic names), and as long as God is sleeping, the guileless soul is tempted (as in the myth about Adam and Eve) and is made to sin because of its weakness. The fairy tale ends with a meaningful statement that the host «woke up ...» [7, p.112]. Readers have the opportunity to invent the further development of the events. Thus, «Just a Tale» is not as simple as it might seem at first glance, it contains a global allegory of the fundamentals of human existence and world views.

The seventh «Tale of How Dangerous it is for Girls to Walk in a Crowd along Nevsky Prospect» is about a group of girls who enter a fashion shop and, after leaving it, fail to notice the absence of one of their companions. An owner of the shop (a foreigner) bewitches the poor girl, takes away her natural beauty and instead gives her the artificial beauty of a doll. A young man takes the doll home. However, being tormented by the doll's utter lack of spirit, he throws her away. This fairy tale is perhaps the only one that was approved by the critics of V. F. Odoyevsky within his lifetime, probably because of the didactic tone and presence of morality concerning the true value of foreign education and its insidious effects, clearly illustrated by the writer on the basis of the simple plot. In support of this interpretation, it is essential to clarify the meaning of some details of the fairy tale. First of all, it is a fairy tale which points out the threat posed to Russian education by any foreign education. From the author's point of view, the native education is a priori natural, meeting the needs of the Slavic soul, whose symbol in the fairy tale is the Russian beauty. This generalization enlarges the scale of the tale: instead of boring moral teaching on the subject of mistakes of social education, the theme is introduced of the preservation of national priorities and values as a global system for the enlightenment of Russian youth - the bearers of the Russian culture, language and traditions. The idea is clear that consciousness determines reality, but if superconsciousness is reduced to a primitive level, reality becomes triumphant, turning superconsciousness to dust.

The eighth tale is "The Same Tale, Only in Reverse» and actually contains two tales (the second one is «The Wooden Guest, or the Tale of the Awakened Doll and Mister Kivakel», 
although it is a mirror return of the previous tale of the girls on Nevsky Prospect, but it has an introduction that is not textually connected with the next tale). Placed together in one chapter, the fairy tales are indicated in their contents as two separate entities. This is due to numerological symbolism (it is necessary to introduce nine tales) and to the fragmentation of a long and unwieldy title.

The text of the preface to the fairy tale of the wooden guest does not include any actions, containing only the author's reflection on the fundamental difference between those who represent the social class of commoners and those who belong to the upper class of aristocrats. A brief analysis is made of the narrowed ideological platform of all members of the lower class. Their characteristics and qualities include inability to perceive different points of view, envy of the wealthy members of society, inability to understand the fine arts, ignorance of etiquette and lack of understanding of its social significance, absence of shame about their own stupidity, etc. Their nonrecognition of this fact is the confirmation of their own «mediocrity» and profanity, whereas at the opposite social pole there is intelligence, love, education, high humility of spirit. Thus, an apologetic of the aristocracy is introduced in pure form which directly dictates the special noble behaviour, thinking, education, lifestyle of its bearers; they, in turn, are the subtle social stratum, whose mission is to save and accumulate the cultural and intellectual wealth of the nation. Of course, the aristocracy has its faults, but the author only refers to them briefly, without focusing attention on them.

The purpose of the introduction to "The Same Tale, Only in Reverse» is to manifest the idea of existence of foolish men as image-symbols of the unenlightened body. In order to describe the polarity of soul/body, the ninth tale «The Wooden Guest» is introduced, which is divided into two logical parts - the theoretical (the ideal model of the perfect person) and the practical (the result of the implementation of this model in society). In accordance with the author's idea, the model of the perfect person includes the divine soul (the beauty from fairy tales) and a beautiful body (a young man, the beloved of the beauty). In order to be beautiful, the soul-beauty must be surrounded with the harmony of music and poetry, emit light, possess the art of suffering and thinking. The beauty-soul should also have the ideal physical body, i. e. that of the beloved man. However, the perfect image is deformed by material life, and the soul meets (to her horror) a miserable creature with a large belly, small swaying head, absence of eloquence and the mocking name Kivakel on his narrow forehead. This is the explanation of the strange title of the fairy tale - "The Wooden Guest, or Tale of the Awakened Doll and Mister Kivakel» The soul is in an excited state, but the body in its physical evolution does not match the soul - a sedentary, phlegmatic or «wooden» hulk, not enlightened with the divine energy of the beautiful soul. It represents a man, arrested in his evolution, who is a guest at the bright celebration of life. He does not have the slightest ray of thought in his head, and his imagination is not enlivened. Mr. Kivakel has completely ceased in his development, which is why he is wooden. The only thing he is capable of doing is endlessly nodding his head as a sign of agreement with everything he is told. With the help of this character, the author introduces the image-symbol of the inertia of the material human body, that (without assistance of the creative nature of the divine soul) is not able to overcome the roughness of physical substance and perceive more subtle energies in order to raise his spirit above the mortal world. The beauty-soul does her best to help the body to revive the rough, humble creature and, in this way, fulfill the elevated destiny of woman in the world, but, unfortunately, she fails. The whole splendour and diversity of the world is beyond the attention and perception of the "wooden» Kivakel. Moreover, he considers the beauty-soul to be his slave and tries, by all means, to transform her according to his own primitive taste and simplified profane model. The end of this slavery is easily predicted: the death of the tormented, tortured soul when her reserve of energy and patience is exhausted.

In a brief epilogue the author bitterly states that he is among the dolls, who try to act like people in real life, but the horror of the situation lies in the fact that all of them are «wooden» and, therefore, incapable of development and evolution. 


\section{Conclusion.}

Within the writer's lifetime, only a few of his fairy tales, taken out of the general context of the cycle «Motley Tales», were analyzed. This led to misunderstanding and distortion of the ideas in every fairy tale, resulting in a lack of appreciation of the ideological richness of V. F. Odoyevsky's works. «Motley Tales» represents a completed cycle of works introducing the principal aspects of alchemical theory and practice, which is why it is inadmissible to interpret them in isolation from each other, because this would violate the integrity of the author's idea. On the basis of our analysis, it could be stated that the conceptual key to the cycle is alchemical symbolism, used in bright and unusual image-symbols. The philosophical ideas of the writer are originally manifested in the form of alchemical allegories with a ciphered esoteric context, in which there are at least two levels of interpretation. The ideological platform of «Motley Tales» is based on the esoteric background of the world, deeply rooted in the mystical fundamentals of existence, which is symbolically and allegorically expressed through alchemical terminology, the correspondence of alchemical reactions and numerological symbolism. It can be stated with confidence that V. F. Odoyevsky is the narrator and writer of this cycle of fairy tales, into which he poured his personal mystical experience.

\section{References:}

[1]. Evdokimova O. V., Our predecessors' works (the works by V. F. Odoyevsky for children), in: Litetature for children, Collection of articles, Issue 31, Leningrad, 1988, pp. 73-89.

[2]. Zhirmunsky V., German romanticism and modern mysticism, St. Petersburg, 1996.

[3]. Zenkovsky V.V., Russian thinkers and Europe, Republic, Moskow, 1997.

[4]. Lobytsina M. V., Peculiarities of Russian fantastical story of 1820-1830 years (N. V. Gogol, V. F. Odoyevsky), Abstract of Candidate dissertation, Moskow, 1991.

[5]. Maimin E. A., Vl. Odoyevsky and his novel «Russian nights», in: Odoyevsky V. F., Russian nights, Leningrad, 1975, pp. 247-276.

[6]. Mikhaylovskaya N. M., V. F. Odoyevsky - the representative of the Russian Enlightment, J. Russian litarature, 1 (1979) 14-25.

[7]. Odoyevsky V. F., Motley Tales with Witticisms, The facsimile reproduction of the edition of 1833, Moscow, Kniga, 1991.

[8]. Peskov A. M., The sources of Russian philosophizing; German roots of mysteries of philosophy-lovers, J. Problems of Philosophy, 5 (1994) 89-100.

[9]. Sakulin P. N., From History of Russian Idealism, Prince V. F. Odoyevsky, Philosopher, Vol. 1, Part 2, Moskow, 1913.

[10]. Sakharov V. I., Romanticist and realists, J. Rising, 6 (1984) 119-123.

[11]. Sakharov V. I., Hieroglyphs of masons, Freemasonry and Russian literature in XVIII - XIX centuries, Moskow, 2000.

[12]. Turian M. A. «Igosha» by V. F. Odoyevsky, in: J. Russian literature, 1 (1997) 132-136.

[13]. Turian M. A., Evolution of romantic motives in the story «Salamandra» by Odoyevsky, in: Russian romantism, Leningrad, 1978, pp. 187-206.

[14]. Turian M. A., «My strange destiny», Life of Vladimir Fedorovich Odoyesky, Moskow, 1991.

[15]. Turian M. A., Preface and addition to the facsimile reproduction of the edition of 1833, in:

Odoyevsky V. F., Motley Tales with Witticisms, Moskow, Kniga, 1991, pp. 3-48.

[16]. Emirsuinova N. K., Antiutopias of V. Odoyevsky, in: Culture and values, Collection of articles, Tver, 1992, pp. 113-118. 